\title{
Faktor- Faktor yang Mempengaruhi Depresi Anak Usia Sekolah: Kajian Literatur
}

\author{
Iga Ayu Saputri ${ }^{1}$, Artika Nurrahima ${ }^{1 *}$ \\ ${ }^{1}$ Departemen Ilmu Keperawatan Fakultas Kedokteran Universitas Diponegoro, Semarang, Indonesia \\ artikanurrahima@fk.undip.ac.id
}

\begin{abstract}
Introduction: School-age children are a vulnerable group who have a high risk of experiencing psychosocial problems, one of which is depression. School-age children who experience depression have adverse effects, such as increasing the risk of committing suicide, being dragged into bad habits, and falling into alcohol abuse, or other drugs as a way to calm down to feel better. Depression is caused by several factors, by knowing these factors can be done to prevent depression in school-age children, so that the incidence of depression in school-age children can be minimized. This study aims to determine the factors that influence depression in school-age children.

Methods: The method used in this research is the study of literature. Researchers reviewed 10 articles sourced from Google Scholar, Science Direct, and Springer Link with keywords risk factor, depression, and school-age children.

Results: The results of the literature study indicate that the factors that influence depression in schoolage children, namely the pressure experienced every day, the school environment, family environment, family finances, maternal depression, premature, and emotional intelligence.

Conclusion: Further quantitative research on the factors that influence depression can provide a real picture of the causes of depression in school-aged children in Indonesia.
\end{abstract}

Keywords: Depression, Risk Factor, School-Age Children.

\begin{abstract}
Abstrak
Pendahuluan: Anak usia sekolah merupakan kelompok rentan yang memiliki risiko tinggi mengalami masalah-masalah psikososial, salah satunya depresi. Anak usia sekolah yang mengalami depresi mempunyai dampak buruk, seperti meningkatkan risiko untuk melakukan bunuh diri, terseret kepada kebiasaan buruk, dan terjerumus penyalahgunaan alkohol, atau obat lain sebagai cara untuk menenangkan diri agar merasa lebih baik. Depresi disebabkan oleh beberapa faktor, dengan mengetahui faktor-faktor tersebut dapat dilakukan upaya pencegahan terjadi depresi pada anak usia sekolah, sehingga kejadian depresi pada anak usia sekolah dapat diminimalisir. Penelitian ini bertujuan untuk mengetahui faktor-faktor yang mempengaruhi depresi pada anak usia sekolah.

Metode: Metode yang digunakan dalam penelitian ini adalah studi literatur. Peneliti mengkaji sepuluh artikel bersumber dari Google Scholar, Science Direct, dan Springer Link dengan kata kunci faktor yang mempengaruhi, depresi, dan anak usia sekolah.

Hasil: Hasil studi literatur menunjukkan bahwa faktor yang mempengaruhi depresi anak usia sekolah, yaitu tekanan yang dialami setiap hari, lingkungan sekolah, lingkungan keluarga, finansial keluarga, depresi ibu, prematur, dan kecerdasan emosional.

Kesimpulan: Penelitian kuantitatif lebih lanjut mengenai faktor yang mempengaruhi depresi dapat memberikan gambaran nyata penyebab depresi pada anak usia sekolah di Indonesia.
\end{abstract}


Kata kunci: Anak Usia Sekolah, Depresi, Faktor yang Mempengaruhi.

\section{PENDAHULUAN}

Sekitar 5\% dari anak-anak dan remaja di Indonesia mengalami depresi pada suatu titik waktu tertentu (Haryanto, Wahyuningsih, \& Nandiroh, 2015). Ikatan Dokter Anak Indonesia (IDAI) Yogyakarta mengungkapkan sekitar 3\% anak usia sekolah dan $6 \%$ remaja di Indonesia mengalami gangguan depresi berat (Indarto, 2017). Penelitian di Bantul, Yogyakarta pada tahun 2009 menunjukkan hasil anak usia 10-12 tahun mengalami depresi dengan prevalensi depresi ringan sebanyak 54,83\%, depresi sedang sebanyak $38,7 \%$, dan $6,45 \%$ pada tingkat depresi berat (Fitriana \& Suryani, 2009).

Depresi adalah emosi atau gangguan alam perasaan yang disertai dengan komponen psikologik dan komponen somatik, komponen psikologik meliputi murung, sedih, putus asa, rasa susah dan tidak bahagia, serta komponen somatik seperti konstipasi, anoreksia, kulit lembap (rasa dingin), nadi dan tekanan darah menurun (Yosep, 2009). Depresi dapat ditandai dengan gejala seperti kelelahan, putus asa, perubahan pola tidur dan nafsu makan, anhedonia, serta bunuh diri (Haryanto et al., 2015). Depresi tidak hanya terjadi pada orang dewasa, anakanak juga dapat mengalami depresi.

Anak usia sekolah merupakan kelompok rentan yang memiliki risiko tinggi mengalami masalah-masalah psikososial. Suatu penelitian menyebutkan bahwa anak yang mengalami depresi mempunyai gejala seperti tidak pernah merasa puas, merasa hidupnya jemu, selalu merasa putus asa, diam dalam waktu lama dan tidak mau berbicara, merasa sedih hingga dihinggapi ketakutan dan kegelisahan, kesadaran menjadi kabur, pikirannya menjadi campur aduk, dan tidak mengenal pantangan serta larangan (Puspitosari, 2010).

Depresi dapat dikarenakan beberapa faktor, seperti genetik, psikososial, kepribadian, psikodinamika, kegagalan, dan kognitif. Anak-anak dan remaja yang depresi akan meningkatkan risiko untuk melakukan bunuh diri karena merasa tertekan, bahkan mengatakan ingin mati atau mungkin berbicara tentang bunuh diri. Depresi yang dialami anak dan remaja juga bisa menyeret kepada kebiasaan buruk dan terjerumus penyalahgunaan alkohol, atau obat lain sebagai cara untuk menenangkan diri agar merasa lebih baik (Haryanto et al., 2015).

Penelitian yang membahas depresi pada anak telah dilakukan mengenai percobaan bunuh diri pada anak dan remaja yang depresi (Supyanti \& Wahyuni, 2012). Suatu penelitian juga membahas bahasa yang digunakan anak depresi yang ketergantungan obat (Puspitosari, 2010). Penelitian lain membahas tentang sistem deteksi depresi pada anak dan remaja (Haryanto et al., 2015). Penelitian lain yang menelaah mengenai faktor-faktor yang mempengaruhi depresi pada anak, seperti tekanan yang dialami setiap hari, konflik keluarga, ekonomi keluarga, dan lingkungan sekolah (Tannous, 2011). Dari penelitian-penelitian tersebut menunjukkan bahwa secara khusus penelitian tentang depresi pada anak usia sekolah telah dilakukan. Penelitian mengenai faktorfaktor yang mempengaruhi depresi pada anak di luar Indonesia masih sebatas penelitian kuantitatif dan belum mencakup banyak faktor. Oleh karena itu, peneliti tertarik untuk meneliti lebih lanjut mengenai faktor-faktor yang mempengaruhi depresi pada anak usia 
sekolah, dengan mengetahui faktor tersebut dapat dilakukan upaya-upaya pencegahan lebih dini, sehingga dapat mengurangi angka depresi pada anak usia sekolah.

\section{METODE}

Metode penelitian yang digunakan adalah kajian literatur atau literature review. Metode pencarian literatur yang digunakan dalam penelitian ini adalah dengan melakukan pencarian bahan literatur di situs jurnal Indonesia seperti Researchgate dan situs jurnal web internasional seperti Science Direct,
EBSCOhost, Cambridge Core, JSTOR, emerald insight, ClinicalKey, ProQuest, nature, Google Scholar, Elsevier dan SpringerLink. Literature yang digunakan dalam penelitian memiliki rentang publikasi sepuluh tahun terakhir dengan kata kunci depresi, faktor yang mempengaruhi, anak usia sekolah, depression, risk factor, dan school-age children. Literatur yang digunakan merupakan artikel dengan berbahasa Indonesia atau berbahasa Inggris yang memenuhi kriteria populasi yaitu anak usia sekolah dengan rentang usia 6-12 tahun.

\section{HASIL}

Tabel 1. Identitas Jurnal

\begin{tabular}{|c|c|c|c|c|}
\hline No. & Penulis/Tahun & Judul Jurnal & Jurnal & Kualifikasi \\
\hline 1. & Adel Tannous (2011) & $\begin{array}{l}\text { Factors causing depression among } \\
\text { children in Jordan: what teachers } \\
\text { see }\end{array}$ & $\begin{array}{l}\text { Procedia-Social } \\
\text { and Behavioral } \\
\text { Sciences }\end{array}$ & Scopus \\
\hline 2. & Jaana Minkkinen (2014) & $\begin{array}{l}\text { Associations between school-related } \\
\text { factors and depressive symptoms } \\
\text { among children: A comparative } \\
\text { study, Finland and Norway }\end{array}$ & $\begin{array}{l}\text { School } \\
\text { Psychology } \\
\text { International }\end{array}$ & Scopus \\
\hline 3. & $\begin{array}{l}\text { Huiping Zhanga, Peilian } \\
\text { Chic, Haili Long, \& Xiaoying } \\
\text { Ren (2019) }\end{array}$ & $\begin{array}{l}\text { Bullying victimization and } \\
\text { depression among left-behind } \\
\text { children in rural China: Roles of } \\
\text { self-compassion and hope }\end{array}$ & $\begin{array}{l}\text { Child Abuse \& } \\
\text { Neglect }\end{array}$ & Scopus \\
\hline 4. & $\begin{array}{l}\text { Rhonda C. Boyd \& Christine } \\
\text { Waanders (2013) }\end{array}$ & $\begin{array}{l}\text { Protective factors for depression } \\
\text { among African American children of } \\
\text { predominantly low-income mothers } \\
\text { with depression }\end{array}$ & $\begin{array}{l}\text { Child \& Family } \\
\text { Studies }\end{array}$ & Scopus \\
\hline 5 . & $\begin{array}{l}\text { Brian LaGrant, } \text { Belinda } \\
\text { Oyinkan Marquis, Anne T. } \\
\text { Berg, Zachary M. Grinspan } \\
(2019)\end{array}$ & $\begin{array}{l}\text { Depression and anxiety in children } \\
\text { with epilepsy and other chronic } \\
\text { health conditions: National estimates } \\
\text { of prevalence and risk factors }\end{array}$ & $\begin{array}{l}\text { Epilepsy } \\
\text { Behavior }\end{array}$ & Scopus \\
\hline 6. & $\begin{array}{l}\text { Jin-Ding Lin, Ho-Jui Tung, } \\
\text { Yu-Hsin Hsieh, Fu-Gong Lin } \\
\text { (2011) }\end{array}$ & $\begin{array}{l}\text { Interactive effects of delayed bedtime } \\
\text { and family-associated factors on } \\
\text { depression in elementary school } \\
\text { children }\end{array}$ & $\begin{array}{l}\text { Research in } \\
\text { Developmental } \\
\text { Disabilities }\end{array}$ & Scopus \\
\hline 7. & $\begin{array}{l}\text { Jin-Ding Lin, Yu-Hsin Hsieh, } \\
\text { Fu-Gong Lin (2013) }\end{array}$ & $\begin{array}{l}\text { Modification effects of family } \\
\text { economic status and school factors } \\
\text { on depression risk of single-father } \\
\text { family children in Mid-Taiwan area }\end{array}$ & $\begin{array}{l}\text { Research in } \\
\text { Developmental } \\
\text { Disabilities }\end{array}$ & Scopus \\
\hline 8. & $\begin{array}{l}\text { Ana Vilela Mendes, Sonia } \\
\text { Regina Loureiro, José } \\
\text { Alexandre Crippa, Carolina } \\
\text { de Meneses Gaya, Lluisa } \\
\text { García-Esteve, and Rocio }\end{array}$ & $\begin{array}{l}\text { Mothers with Depression, School- } \\
\text { Age Children with Depression? A } \\
\text { Systematic Review }\end{array}$ & $\begin{array}{l}\text { Perspectives in } \\
\text { Psychiatric } \\
\text { Care }\end{array}$ & Scopus \\
\hline
\end{tabular}




\begin{tabular}{|c|c|c|c|c|}
\hline No. & Penulis/Tahun & Judul Jurnal & Jurnal & Kualifikasi \\
\hline & Martín-Santos (2012) & & & \\
\hline 9. & $\begin{array}{l}\text { Adel Tannous, Jehan Matar } \\
\text { (2010) }\end{array}$ & $\begin{array}{l}\text { The Relationship between depression } \\
\text { and emotional intelligence among a } \\
\text { sample of Jordanian children }\end{array}$ & $\begin{array}{l}\text { Procedia Social } \\
\text { and Behavioral } \\
\text { Sciences }\end{array}$ & Scopus \\
\hline 10. & $\begin{array}{l}\text { Chiu Ting-Fanga, Yu Tung- } \\
\text { Min, Chuang Ya-Wen, Sun } \\
\text { Kuo-Tingb, Li Chi-Yuan, } \\
\text { Su Yuan-Chih, Kao Chia- } \\
\text { Hung (2019) }\end{array}$ & $\begin{array}{l}\text { Sequential risk of depression in } \\
\text { children born prematurely: A } \\
\begin{array}{l}\text { nationwide population- based } \\
\text { analysis }\end{array}\end{array}$ & $\begin{array}{l}\text { Journal of } \\
\text { Affective } \\
\text { Disorders }\end{array}$ & Scopus \\
\hline
\end{tabular}

Tabel 2. Matriks Ide Pokok Artikel

\begin{tabular}{|c|c|}
\hline $\begin{array}{c}\text { Sumber } \\
\text { (penulis \& tahun) }\end{array}$ & Deskripsi topik/isu \\
\hline Adel Tannous (2011) & $\begin{array}{l}\text { Faktor penyebab depresi anak berdasarkan persepsi guru meliputi tekanan } \\
\text { yang dialami tiap hari, konflik keluarga, ekonomi keluarga, lingkungan } \\
\text { sekolah. }\end{array}$ \\
\hline Jaana Minkkinen (2014) & $\begin{array}{l}\text { Anak yang mempunyai hubungan buruk di sekolah berisiko mengalami } \\
\text { depresi. }\end{array}$ \\
\hline $\begin{array}{l}\text { Huiping Zhang, Peilian Chic, Haili } \\
\text { Long, \& Xiaoying Ren (2019) }\end{array}$ & $\begin{array}{l}\text { Bullying viktimisasi mempunyai pengaruh terhadap depresi dan didukung } \\
\text { faktor lain seperti welas asih dan harapan. }\end{array}$ \\
\hline $\begin{array}{l}\text { Rhonda C. Boyd \& Christine } \\
\text { Waanders (2013) }\end{array}$ & $\begin{array}{l}\text { Terdapat hubungan antara pengasuhan dan keterampilan sosial dengan } \\
\text { depresi pada anak. }\end{array}$ \\
\hline $\begin{array}{l}\text { Brian LaGrant, Belinda Oyinkan } \\
\text { Marquis, Anne T. Berg, \& Zachary } \\
\text { M. Grinspan (2019) }\end{array}$ & $\begin{array}{l}\text { Epilepsi menjadi salah satu faktor penyebab depresi didukung dengan faktor } \\
\text { lain, seperti ras dan ekonomi. }\end{array}$ \\
\hline $\begin{array}{l}\text { Jin-Ding Lin, Ho-Jui Tung, Yu- } \\
\text { Hsin Hsieh, \& Fu-Gong Lin (2011) }\end{array}$ & $\begin{array}{l}\text { Anak yang waktu tidurnya lebih dari jam } 10 \text { malah dan didukung dengan } \\
\text { lingkungan keluarga yang buruk akan mengembangkan depresi anak. }\end{array}$ \\
\hline $\begin{array}{l}\text { Jin-Ding Lin, Yu-Hsin Hsieh, \& } \\
\text { Fu-Gong Lin (2013) }\end{array}$ & $\begin{array}{l}\text { Struktur keluarga menyumbang penyebab depresi pada anak, terutama pada } \\
\text { anak dengan keluarga ayah tunggal. }\end{array}$ \\
\hline $\begin{array}{l}\text { Ana Vilela Mendes, Sonia Regina } \\
\text { Loureiro, José Alexandre Crippa, } \\
\text { Carolina de Meneses Gaya, Lluisa } \\
\text { García-Esteve, \& Rocio Martín- } \\
\text { Santos (2012) }\end{array}$ & $\begin{array}{l}\text { Depresi ibu memiliki hubungan dengan depresi anak yang dimedia oleh } \\
\text { beberapa faktor, yaitu lingkungan keluarga, penyesuaian perkawinan, } \\
\text { dukungan sosial, faktor klinis depresi, dan variabel yang berhubungan } \\
\text { dengan anak. }\end{array}$ \\
\hline $\begin{array}{l}\text { Adel Tannous, \& Jehan Matar } \\
(2010)\end{array}$ & $\begin{array}{l}\text { Anak yang memiliki kecerdasan emosional yang buruk lebih berisiko untuk } \\
\text { mengalami depresi. }\end{array}$ \\
\hline $\begin{array}{l}\text { Chiu Ting-Fanga, Yu Tung-Min, } \\
\text { Chuang Ya-Wen, Sun Kuo-Tingb, } \\
\text { Li Chi-Yuan, Su Yuan-Chih, \& } \\
\text { Kao Chia-Hung (2019) }\end{array}$ & $\begin{array}{l}\text { Anak yang lahir prematur berisiko } 2,75 \text { kali lebih tinggi mengalami depresi } \\
\text { dibanding dengan anak yang lahir cukup bulan. }\end{array}$ \\
\hline
\end{tabular}

\section{PEMBAHASAN}

\section{Lingkungan Keluarga}

Lingkungan keluarga meliputi struktur keluarga, pola asuh, maupun konflik keluarga. Anak dengan depresi memiliki proporsi lebih tinggi mengalami tekanan di iklim keluarga yang tidak harmonis, anak dengan keluarga yang penuh konflik cenderung diabaikan (Lin, Tung, Hsieh, \& Lin, 2011; Tannous, 2011). Anak dengan keluarga ayah tunggal juga menjadi salah satu faktor penyebab depresi. Penelitian menunjukkan anak dengan ayah tunggal memiliki risiko mengalami depresi 
sebanyak tiga hingga lima kali lipat (Lin, Hsieh, \& Lin, 2013). Selain konflik dan struktur keluarga, pola asuh merupakan salah satu penyebab timbulnya depresi pada anak. Hal ini sejalan dengan penelitian sebelumnya yang menunjukkan pola asuh yang positif cenderung memiliki gejala depresi yang rendah (Boyd \& Waanders, 2013). Orang tua yang mengabaikan anak cenderung tidak memperdulikan kebutuhan emosional anak mereka, sehingga menimbulkan dampak negatif pada perkembangan anak. Konflik keluarga membuat hubungan keluarga dan anak tidak dekat, hal ini menyebabkan anak sulit untuk mengekspresikan dirinya saat di rumah. Sedangkan pola asuh yang buruk membuat anak merasa tertekan ketika berada di rumah, sehingga anak cenderung berperilaku negatif seperti melanggar aturan, murung, dan kurang ekspresif yang mana hal tersebut dikaitkan dengan gejala depresi.

\section{Lingkungan Sekolah}

Anak melakukan interaksi dengan guru maupun teman sebayanya di sekolah. Guru dapat menjadi salah satu faktor timbulnya depresi pada anak. Sikap guru yang dapat menyebabkan depresi anak berupa melakukan diskriminasi, membuat komentar pedas, mempermalukan anak di depan teman sekelasnya, dan mencegah anak bermain dengan temannya (Tannous, 2011). Selain sikap guru, teman sebaya atau teman satu sekolah juga dapat menimbulkan depresi pada anak. Penelitian menunjukkan adanya hubungan yang kuat antara teman sebaya dengan gejala depresi pada anak (Lin et al., 2011; Minkkinen, 2014). Anak yang memiliki hubungan yang buruk di sekolah baik dengan guru ataupun teman memiliki hubungan dengan kinerja sekolah yang buruk dan gejala depresi pada anak. Ketika anak mendapatkan perlakuan yang buruk oleh guru atau mengalami hubungan yang tidak baik dengan temannya, anak akan merasa sedih, suka menyendiri, tidak memiliki teman, tidak bersemangat, mengalami tekanan hingga membenci sekolah, yang mana hal tersebut dikaitkan dengan timbulnya gejala depresi pada anak.

\section{Tekanan yang Dialami Setiap Hari}

Tekanan yang dialami anak meliputi keadaan lingkungan, cacat fisik, penyakit fisik, dan kondisi kronis (Tannous, 2011). Kedaan lingkungan yang membuat anak tertekan salah satunya perilaku bullying. Penelitian membuktikan bullying viktimisasi mempunyai hubungan dengan depresi (Zhang, Chi, Long, \& Ren, 2019). Hal ini dibuktikan bahwa anak yang mengalami bullying viktimisasi dan ditinggalkan orang tuanya melaporkan kejadian depresi lebih banyak karena anak tidak mendapatkan perlindungan dari orang tua mereka. Faktor ini juga didukung dengan welas asih dan harapan anak, anak yang mempunyai welas asih dan harapan lebih kecil mengalami depresi (Zhang et al., 2019).

Selain bullying viktimisasi, kondisi kronis dapat menimbulkan tumbuhnya depresi. Hal ini sejalan dengan penelitian yang membuktikan bahwa epilepsi mempunyai hubungan dengan depresi pada anak. Penelitian ini membuktikan sebanyak $13,1 \%$ anak yang menderita epilepsi mengalami depresi (LaGrant, Marquis, Berg, \& Grinspan, 2019). Anak-anak dengan epilepsi yang kebutuhan perawatan spesialisnya tidak terpenuhi lebih cenderung mengalami depresi. Stres yang dialami oleh anak karena penyakitnya memperpanjang perasaan depresi. Anakanak dengan obesitas sering mengalami masalah dalam harga diri dan sering mengalami diskriminasi yang memiliki hubungan erat kaitannya dengan peningkatan risiko depresi. 


\section{Ekonomi Keluarga}

Stres ekonomi dapat menyebabkan orang tua mengalami depresi (Boyd \& Waanders, 2013; Tannous, 2011). Anak yang tinggal dalam lingkungan depresif akan menimbulkan perilaku depresif. Keluarga dengan penghasilan rendah memungkinkan anak mengalami masalah kesehatan mental (Lin et al., 2013). Penelitian menunjukkan anak-anak dengan keluarga miskin lebih berisiko mengalami depresi (LaGrant et al., 2019). Ekonomi keluarga yang buruk membuat keluarga sering mengalami konflik yang membuat suasana keluarga menjadi negatif. Keadaan ekonomi keluarga yang buruk menyebabkan orang tua mencari pekerjaan tambahan bahkan sampai meninggalkan keluarga untuk merantau. Anak yang mengalami perpisahan dengan orang tua karena pekerjaan membuat anak jauh dari orang tua dan menimbulkan perasaan sedih pada anak.

\section{Waktu Tidur}

Waktu tidur memiliki pengaruh terhadap pengembangan depresi pada anak. hal ini sejalan dengan penelitian sebelumnya yang menyebutkan kebiasaan tidur dan faktor keluarga memiliki hubungan dengan depresi (Lin et al., 2011). Data penelitian menunjukkan bahwa anak-anak yang tidur setelah jam 10 malam memiliki risiko depresi yang secara signifikan lebih tinggi daripada anak-anak yang tidur sebelum jam 10 malam terlepas dari waktu bangun dalam model regresi logistik yang disesuaikan, hal ini akan berisiko 4,35 kali lebih besar jika anak berada dalam lingkungan keluarga yang kurang harmonis (Lin et al., 2011). Emosi anak akan dipengaruhi oleh hubungan antara orang tua dan anak yang menyebabkan tidur larut malam, anak yang memiliki kebiasaan tidur yang buruk mempengaruhi kinerja akademik anak yang dihubungkan sebagai salah satu penyebab depresi anak. Oleh karena itu, tersirat bahwa waktu tidur yang tertunda memediasi lama tidur anak-anak sekolah dan kemudian mempengaruhi status depresi pada anak.

\section{Prematur}

Penelitian yang dilakukan di China menunjukkan bahwa anak yang lahir prematur memiliki risiko depresi 2,75 kali lebih tinggi dibanding anak yang tidak prematur (Chiu et al., 2019). Hal itu didukung dengan beberapa faktor, seperti tempat tinggal anak dan pekerjaan orang tua. Anak yang tinggal di daerah urbanisasi rendah lebih berisiko jika dibandingkan dengan anak yang tinggal di daerah dengan urbanisasi tinggi, begitu pula dengan anak yang orang tuanya merupakan pekerja kasar (Chiu et al., 2019). Anak prematur dengan orang tua pekerja kasar mengalami depresi 3,4 kali lebih tinggi dibandingkan dengan anak yang lahir cukup bulan (Chiu et al., 2019). Anak yang lahir prematur mendapatkan intervensi penyelamatan hidup saat masih neonates, sehingga anak mengalami stres. Saat anak masih neonatus dapat mengalami kesulitan untuk memanaj stres yang menyebabkan mengurangi ketahanan tubuh dan memperpanjang stres hidup. Stres yang dialami anak saat neonatus dapat mempengaruhi timbulnya depresi saat anak mengalami pertumbuhan dan perkembangan.

\section{Depresi Ibu}

Depresi yang dialami ibu menyebabkan anak memiliki risiko adanya gejala depresi. Hal ini dipengaruhi oleh faktor lain seperti perkawinan, lingkungan keluarga, ekonomi, pola asuh dan dukungan sosial (Boyd \& Waanders, 2013; Mendes et al., 2012). Dalam hal ini, ibu dengan depresi mengalami kesulitan untuk mengasuh anak, ibu dengan depresi 
mengungkapkan bahwa mereka kurang efektif saat berkomunikasi, kurang responsif terhadap anak, dan kurang berinteraksi secara positif (Mendes et al., 2012). Hal tersebutlah yang menyebabkan anak mengalami kurangnya dukungan dari ibu, sehingga sulit untuk melewati tugas perkembangan mereka. Namun, apabila anak memiliki keterampilan sosial yang baik walaupun mendapatkan pola asuh yang buruk, anak dapat menghindari timbulnya gejala depresi. Hal ini sejalan dengan penelitian sebelumnya yang menunjukkan bahwa keterampilan sosial merupakan faktor pelindung anak dari depresi (Boyd \& Waanders, 2013). Keterampilan sosial yang baik yang dimiliki oleh anak akan membantu anak mendapatkan dukungan dari lingkungannya, sehingga timbul rasa percaya diri dan semangat pada anak, hal tersebut berkebalikan dengan tanda gejala depresi.

\section{Kecerdasan Emosional}

Kecerdasan emosional menjadi salah satu faktor yang mempengaruhi depresi (Tannous \& Matar, 2010). Individu dengan kecerdasan emosional yang lebih tinggi dapat mengurangi risiko timbulnya depresi. Kecerdsan emosional dinilai mampu mengelola dan mengekspresikan emosi seseorang sehingga memiliki keterampilan sosial yang baik. Keterampilan sosial merupakan salah satu faktor pelindung timbulnya depresi (Boyd \& Waanders, 2013). Individu dengan kecerdasan emosional yang baik juga menunjukkan keterampilan pemecahan masalah, mampu mengatur emosi, dapat mengendalikan impuls dengan terampil. Berdasarkan perkembangan kognitif anak usia sekolah, anak akan mulai mulai dapat berpikir logis dan mulai bisa menyimpulkan informasiinformasi yang diterima, dengan kecerdasan emosional anak yang baik, anak akan mampu melewati tugas perkembangan kognitifnya. Selain itu, anak dengan kecerdasan emosional yang baik membuat anak mampu mentoleransi stress. Individu yang mampu mengatasi stresnya dengan koping yang baik dapat mengurangi kemungkinan terjadinya depresi.

\section{KESIMPULAN DAN SARAN}

Berdasarkan dari analisis hasil dan pembahasan yang telah dilakukan, peneliti dapat menarik simpulan bahwa depresi pada anak usia sekolah dapat disebabkan oleh beberapa faktor, yaitu lingkungan keluarga (struktur keluarga, pola asuh, dan konflik), lingkungan sekolah, tekanan yang dialami setiap hari (cacat fisik, penyakit fisik, lingkungan, dan kondisi kronis, seperti epilepsi), ekonomi keluarga, waktu tidur, premature, depresi ibu, dan kecerdasan emosional. Penelitian lanjut tentang faktor yang paling berpengaruh terhadap timbulnya depresi pada anak usia sekolah perlu untuk dilakukan.

\section{DAFTAR PUSTAKA}

Boyd, R. C., \& Waanders, C. (2013). Protective factors for depression among African American children of predominantly low-income mothers with depression. Journal of Child and Family Studies, 22(1), 85-95. doi: 10.1007/s10826-012-9588-y

Chiu, T. F., Yu, T. M., Chuang, Y. W., Sun, K. T., Li, C. Y., Su, Y. C., \& Kao, C. H. (2019). Sequential risk of depression in children born prematurely: A nationwide population- based analysis. Journal of Affective Disorders, 243, 42-47. doi: 10.1016/j.jad.2018.09.019 
Fitriana, A., \& Suryani. (2009). Hubungan faktor psikologis dengan tingkat depresi pada anak usia 10-12 tahun di SD Negeri 3 Sedayu Bantul Yogyakarta. Skripsi STIKes 'Aisyiyah Yogyakarta.

Haryanto, Wahyuningsih, H. D., \& Nandiroh, S. (2015). Sistem deteksi gangguan depresi pada anak-anak dan remaja. Jurnal Ilmiah Teknik Industri, $14(2), 142-152$.

Indarto, F. W. (2017). Depresi pada anak. Diperoleh dari http://www.idaijogja.or.id/depresipada-anak/

LaGrant, B., Marquis, B. O., Berg, A. T., \& Grinspan, Z. M. (2019). Depression and anxiety in children with epilepsy and other chronic health conditions: National estimates of prevalence and risk factors. Epilepsy and Behavior, 103, $106828 . \quad$ doi: 10.1016/j.yebeh.2019.106828

Lin, J. D., Hsieh, Y. H., \& Lin, F. G. (2013). Modification effects of family economic status and school factors on depression risk of single-father family children in Mid-Taiwan area. Research in Developmental Disabilities, 34(5), 1468-1477. doi: 10.1016/j.ridd.2013.01.036

Lin, J. D., Tung, H. J., Hsieh, Y. H., \& Lin, F. G. (2011). Interactive effects of delayed bedtime and familyassociated factors on depression in elementary school children. Research in Developmental Disabilities, 32(6), 2036-2044.

doi: 10.1016/j.ridd.2011.08.011

Mendes, A. V., Loureiro, S. R., Crippa, J. A., Gaya, C. de M., García-Esteve, L.,
\& Martín-Santos, R. (2012). Mothers with depression, school-age children with depression? A systematic review. Perspectives in Psychiatric Care, 48(3), 138-48. doi: 10.1111/j.17446163.2011.00318.x

Minkkinen, J. (2014). Associations between school-related factors and depressive symptoms among children: A comparative study, Finland and Norway. School Psychology International, 35(5), 463-474. doi: $10.1177 / 0143034313511008$

Puspitosari, N. A. (2010). Analisis bahasa depresi pada anak ketergantungan obat di Pondok Metal Pasuruan. Jurnal Artikulasi, 9(1), 641-650.

Supyanti, W., \& Wahyuni, A. (2012). Pencegahan percobaan bunuh diri pada anak dan remaja dengan gangguan depresi. E-Jurnal Medika Udayana, 1(1), 1-10.

Tannous, A. (2011). Factors causing depression among children in Jordan: What teachers see. Procedia - Social and Behavioral Sciences, 30, 341346. doi: 10.1016/j.sbspro.2011.10.067

Tannous, A., \& Matar, J. (2010). The relationship between depression and emotional intelligence among a sample of Jordanian children. Procedia-Social and Behavioral Sciences, 5, 1017-1022. doi: 10.1016/j.sbspro.2010.07.228

Yosep, I. (2009). Keperawatan jiwa (Edisi Revi; A. Gunarsa, Ed.). Bandung: PT Refika Aditama.

Zhang, H., Chi, P., Long, H., \& Ren, X. (2019). Bullying victimization and 
depression among left-behind children in rural China: Roles of selfcompassion and hope. Child Abuse and Neglect, $96, \quad 1-8 . \quad$ doi: 10.1016/j.chiabu.2019.104072 